\title{
Kebijakan Formulasi Sanksi Pidana Kerja Sosial terhadap Orang Membuang Sampah Dari Kendaraan di Kota Jambi
}

\author{
Reza Iswanto ${ }^{1}$ \\ Fakultas Hukum Universitas Batanghari \\ Email: reza.iswanto@unbari.ac.id
}

\begin{abstract}
Abstrak. Sampah merupakan permasalahan di dalam kehidupan masyarakat terutama pada masyarakat kota Jambi sehingga perlu dilakukan penanggulangan terkait dengan sampah itu sendiri. Untuk itu, seharusnya dilakukan pengaturan kembali terkait dengan sanksi bagi orang yang melakukan pembuangan sampah dari kendaraan. Apabila dilihat dari permasalahannya maka metode penelitiannya yaitu penelitian hukum normatif dengan pendekatan perundang-undangan dan pendekatan konseptual. Bahan penelitiannya yaitu bahan hukum primer, sekunder dan tersier dengan teknik pengumpulan data menggunakan studi dokumenter dan teknik analisis kualitatif. Pengaturan sanksi denda terhadap orang membuang sampah dari kendaraan diatur dalam Pasal 46 ayat (3) huruf c Peraturan Daerah Kota Jambi Nomor 5 Tahun 2020 Tentang Pengelolaan Sampah. Kemudian Implikasi sanksi pidana kerja sosial terhadap orang membuang sampah dari kendaraan yaitu memberi efek jera juga memberi pelajaran terhadap pelaku dan kebijakan formulasi sanksi pidana kerja sosial untuk yang akan datang adalah sebaiknya sanksi pidana kerja sosial diberlakukan dalam Peraturan Daerah Kota Jambi Nomor 5 Tahun 2020 Tentang Pengelolaan Sampah karena merupakan suatu upaya penanggulangan agar kedepannya tidak ada lagi masyarakat kota Jambi yang membuang sampah dari kendaraannya.
\end{abstract}

Kata Kunci : Kebijakan, Pidana, Kerja, Sosial, Sampah

\begin{abstract}
Garbage is a problem in people's lives, especially in the people of Jambi city, so it is necessary to deal with waste related to the waste itself. For this reason, there should be a re-arrangement related to sanctions for people who dispose of waste from vehicles. When viewed from the problem, the research method is normative legal research with a statutory approach and a conceptual approach. The research materials are primary, secondary and tertiary legal materials with data collection techniques using documentary studies and qualitative analysis techniques. The regulation of fines for people throwing garbage from vehicles is regulated in Article 46 paragraph (3) letter c Jambi City Regional Regulation Number 5 of 2020 concerning Waste Management. Then the implication of social work criminal sanctions for people throwing garbage from vehicles, namely providing a deterrent effect as well as giving lessons to perpetrators and the policy of formulating social work criminal sanctions for the future is that social work criminal sanctions should be applied in Jambi City Regional Regulation Number 5 of 2020 concerning Management Garbage because it is an effort to overcome so that in the future there will be no more people in the city of Jambi who throw garbage from their vehicles.
\end{abstract}

Keywords: Policy, Criminal, Work, Social, Garbage

\section{PENDAHULUAN}

Sampah merupakan suatu permasalahan yang selalu dihadapi oleh masyarakat karena dengan adanya sampah tersebut tidak menutup kemungkinan akan menimbulkan berbagai macam masalah dalam kehidupan masyarakat seperti penyebaran bau yang tidak sedap dari sampah, polusi udara yang diakibatkan dari pembakaran sampah sampai dengan timbulnya bencana seperti banjir yang diakibatkan oleh sampah itu sendiri. Hal yang demikian tentu harus diperhatikan demi melindungi masyarakat dari berbagai macam bahaya yang akan timbul dari adanya sampah tersebut.

Sebenarnya sampah jika diolah dengan baik akan memberi hasil yang baik pula terhadap masyarakat terutama masyarakat kota Jambi itu sendiri. Namun, terkadang masyarakat kota Jambi sendiri juga yang sukar untuk melakukan pengolahan sampah karena mereka berpikir sampah merupakan suatu kotoran yang tidak dapat diolah untuk dipergunakan kembali. Pemikiran yang seperti inilah yang selalu ada dalam masyarakat termasuk juga masyarakat kota Jambi sehingga di dalam pengelolaan sampah masih dapat dikatakan minim dan hanya orang-orang tertentu saja yang mau melakukan pengelolaan sampah seperti pemulung dan pengepul sampah.

Padahal apabila sampah tersebut dapat diolah oleh masyarakat kota Jambi maka tidak menutup kemungkinan akan memberikan hasil yang memuaskan seperti tidak perlu lagi membeli pupuk karena dengan adanya sampah yang berasal dari sayuran atau tumbuh-tumbuhan dapat dijadikan pupuk atau kompos untuk tanaman yang ada di rumah. Tidak hanya itu saja, apabila sampah organik tersebut dapat diolah oleh masyarakat kota Jambi maka sampah organik tersebut dapat menjadi bahan bakar pengganti gas elpiji untuk kompor gas yang ada di rumah. Apabila dilihat dari hasil yang telah diolah maka sampah tersebut tidak menjadi sia-sia dalam memenuhi kebutuhan masyarakat terutama masyarakat kota Jambi.

\footnotetext{
${ }^{1}$ Dosen Fakultas Hukum Universitas Batanghari
} 
Namun, hal yang demikian masih jauh dari pemikiran masyarakat kota Jambi sehingga masih banyak masyarakat kota Jambi membuang sampah yang seharusnya dapat dipergunakan kembali untuk memenuhi kebutuhan hidupnya sendiri. Selain itu juga, masih banyak masyarakat yang membuang sampah tidak pada tempatnya dan terkadang juga ada masyarakat yang membuang sampah tidak sesuai dengan jadwal yang telah ditentukan oleh pemerintah kota Jambi. Padahal jika dilihat dalam Peraturan Daerah Kota Jambi Nomor 5 Tahun 2020 Tentang Pengelolaan Sampah telah mengatur terkait perbuatan yang dilarang dalam hal sampah. Aturan yang lebih spesifik lagi dapat dilihat dalam Pasal 28 Huruf a Peraturan Daerah Kota Jambi Nomor 5 Tahun 2020 Tentang Pengelolaan Sampah yang berisikan bahwa membuang sampah di luar tempat/lokasi yang telah ditentukan dan disediakan.

Dengan adanya peraturan daerah kota Jambi tersebut maka sudah seharusnya masyarakat kota Jambi mentaati peraturan itu karena peraturan dibuat bertujuan untuk melindungi masyarakat kota Jambi dari berbagai macam bahaya termasuk juga bahaya yang akan ditimbulkan dari sampah itu sendiri. Hal yang demikian juga sependapat dengan pendapat Jeremy Bentham yang pada intinya menjelaskan bahwa hukum itu dibuat dengan tujuan untuk menjamin kebahagiaan terbesar kepada setiap manusia. ${ }^{2}$ Oleh karena itu, apabila tujuan hukum telah memberikan penjaminan atau melindungi diri masyarakat dari berbagai macam bahaya termasuk juga bahaya dari adanya sampah tersebut maka sudah seharusnya masyarakat dalam hal ini Masyarakat Kota Jambi mentaati peraturan yang telah dibuat oleh pemerintah kota Jambi.

Apabila dilihat dari fakta di lapangan masih banyak juga masyarakat kota Jambi yang tidak menaati Peraturan Daerah Kota Jambi Nomor 5 Tahun 2020 Tentang Pengelolaan Sampah terkait dengan pembuangan sampah. Bahkan yang lebih parahnya lagi ada juga masyarakat kota Jambi yang membuang sampah dari kendaraannya di jalan raya. Hal yang demikian tentunya harus diperhatikan oleh pemerintah Kota Jambi terkait dengan larangan terhadap Masyarakat Kota Jambi yang membuang sampah dari kendaraan karena terkait dengan perbuatan tersebut telah diatur di dalam Pasal 28 Huruf e Peraturan Daerah Kota Jambi Nomor 5 Tahun 2020 Tentang Pengelolaan Sampah yang berisikan bahwa setiap orang, pelaku usaha dan atau badan usaha dilarang membuang sampah dan/atau kotoran lainnya dari atas kendaraan.

Pasal 28 Huruf e Peraturan Daerah Kota Jambi Nomor 5 Tahun 2020 Tentang Pengelolaan Sampah ini merupakan peraturan yang bersifat substantif yang mana telah dijelaskan oleh Satjipto Rahardjo terkait dengan peraturan yang bersifat substantif. Adapun penjelasan tentang peraturan yang bersifat substantif yang pada dasarnya yaitu suatu peraturan terkait dengan perbuatan yang boleh dan perbuatan yang tidak boleh dilakukan. ${ }^{3}$ Untuk itu, Jika dilihat dalam Pasal 28 Huruf e Peraturan Daerah Kota Jambi Nomor 5 Tahun 2020 Tentang Pengelolaan Sampah maka sudah jelas dalam aturan tersebut mengatur terkait dengan perbuatan yang tidak boleh dilakukan oleh masyarakat Kota Jambi yaitu membuang sampah dari atas kendaraan.

Dengan adanya pengaturan umum terkait dengan larangan membuang sampah di atas kendaraan maka pemerintah Kota Jambi membuat aturan terkait dengan denda apabila masyarakat Kota Jambi tetap melakukan pembuangan sampah di atas kendaraannya. Adapun sanksi denda yang tercantum di dalam Pasal 46 ayat (3) Huruf c Peraturan Daerah Kota Jambi Nomor 5 Tahun 2020 Tentang Pengelolaan Sampah yaitu setiap orang dengan sengaja atau terbukti membuang sampah dari kendaraan, dikenakan denda minimal Rp. 500.000,- (lima ratus ribu rupiah). Dengan adanya sanksi denda ini maka siapa saja atau masyarakat Kota Jambi yang melakukan perbuatan yang dilarang dalam hal ini membuang sampah di atas kendaraan maka akan dikenakan sanksi denda tersebut karena sesuai dengan perbuatannya yang telah melanggar pasal 28 huruf e Peraturan Daerah Kota Jambi Nomor 5 Tahun 2020 Tentang Pengelolaan Sampah.

Walaupun telah ada sanksi denda terhadap orang yang melakukan pembuangan sampah di atas kendaraan, akan tetapi sanksi denda tersebut dirasakan tidak memberikan efek jera sehingga dikhawatirkan nantinya akan diulangi lagi oleh pelaku yang sama Dalam melakukan perbuatan yang sama pula. Untuk mengantisipasi hal yang demikian maka sudah seharusnya diberlakukan juga sanksi pidana kerja sosial agar masyarakat kota Jambi khususnya pelaku yang melakukan pembuangan sampah di atas kendaraannya mendapatkan pelajaran dari perbuatan yang mana perbuatan yang dilakukan oleh masyarakat atau pelaku tersebut dapat merugikan orang lain dalam menggunakan kendaraan di jalan raya.

Sebenarnya diadakan sanksi pidana kerja sosial ini bertujuan untuk menjadikan hukum pidana lebih berfungsi di dalam masyarakat khususnya masyarakat kota Jambi. Tidak hanya itu saja, dengan adanya sanksi pidana kerja sosial ini juga lebih manusiawi sehingga tidak memberikan stigma yang tidak baik terhadap pelaku atau masyarakat yang telah melakukan pelanggaran dalam membuang sampah di atas kendaraan. Selain itu juga, jika diterapkan sanksi pidana kerja sosial terhadap masyarakat kota Jambi khususnya orang yang membuang sampah di atas kendaraan akan memberikan pembinaan agar tidak melakukan perbuatan yang sama di kemudian hari.

\footnotetext{
${ }^{2}$ Sudikno Mertokusumo, Mengenal Hukum : Sebuah Pengantar, (Yogyakarta : Liberty, 2008), $\quad$ hal 80.

3 Satjipto Rahardjo, Ilmu Hukum, (Bandung : PT. Citra Aditya Bakti, 2000), hal 77.
} 
Mengingat masih banyaknya masyarakat Kota Jambi yang tidak patuh terhadap Peraturan Daerah Kota Jambi Nomor 5 Tahun 2020 Tentang Pengelolaan Sampah khususnya terkait dengan pembuangan smapah di atas kendaraan dan akan berbahaya terhadap pengendara lain maka sudah seharusnya diberlakukan sanksi pidana kerja sosial selain sanksi denda yang ada di dalam Peraturan Daerah Kota Jambi Nomor 5 Tahun 2020 Tentang Pengelolaan Sampah tersebut.

Berdasarkan penjelasan yang telah dijabarkan di atas maka penulis membuat batasan terkait dengan ruang lingkup yang akan dikaji dalam negara ini sehingga memudahkan dalam memahami permasalahan yang sedang diteliti. Adapun ruang lingkup atau batasan permasalahan yang akan diteliti sebagai berikut :

1. Bagaimana pengaturan sanksi denda terhadap orang membuang sampah dari kendaraan dalam Peraturan Daerah Kota Jambi Nomor 5 Tahun 2020 Tentang Pengelolaan Sampah?

2. Bagaimana implikasi sanksi pidana kerja sosial terhadap orang membuang sampah dari kendaraan dalam Peraturan Daerah Kota Jambi Nomor 5 Tahun 2020 Tentang Pengelolaan Sampah?

3. Bagaimana kebijakan formulasi sanksi pidana kerja sosial terhadap orang membuang sampah dari kendaraan dalam Peraturan Daerah Kota Jambi Nomor 5 Tahun 2020 Tentang Pengelolaan Sampah yang akan datang ?

Apabila dilihat dari uraian yang telah dijelaskan pada latar belakang dalam penelitian ini maka penulis membuat suatu tujuan yang akan dihasilkan dalam penelitian ini. Adapun tujuan dari adanya penelitian ini sebagai berikut:

1. Untuk mengetahui pengaturan sanksi denda terhadap orang membuang sampah dari kendaraan dalam Peraturan Daerah Kota Jambi Nomor 5 Tahun 2020 Tentang Pengelolaan Sampah.

2. Untuk memahami implikasi sanksi pidana kerja sosial terhadap orang membuang sampah dari kendaraan dalam Peraturan Daerah Kota Jambi Nomor 5 Tahun 2020 Tentang Pengelolaan Sampah.

3. Untuk menjelaskan kebijakan formulasi sanksi pidana kerja sosial terhadap orang membuang sampah dari kendaraan dalam Peraturan Daerah Kota Jambi Nomor 5 Tahun 2020 Tentang Pengelolaan Sampah yang akan datang.

\section{METODE}

Metode penelitian digunakan untuk mempermudah peneliti dalam melakukan suatu penelitian, dimana metode penelitian ini berkaitan dengan prosedur atau cara yang harus dilakukan peneliti sehingga dengan adanya metode penelitian ini peneliti harus menggunakan langkah-langkah yang teratur dan sistematis di dalam mencari bahan atau sumber data yang diperlukan untuk disajikan dalam suatu penelitian.

Hal yang demikian juga sama dengan pendapat Sukandarrumidi yang menyatakan bahwa metode penelitian merupakan cara utama yang digunakan peneliti untuk mencapai tujuan dan menentukan jawaban atas masalah yang diajukan. ${ }^{4} \mathrm{Jadi}$, metode penelitian itu merupakan suatu cara cara yang digunakan para peneliti dalam memecahkan masalah yang sedang diteliti atau yang sedang dihadapi. Adapun metode penelitian yang digunakan dalam penelitian ini sebagai berikut :

1. Pendekatan

Penelitian tentang kebijakan formulasi sanksi pidana kerja sosial terhadap orang membuang sampah dari kendaraan di Kota Jambi merupakan penelitian hukum normatif. Pada hakekatnya penelitian normatif merupakan penelitian yang mengkaji dan menganalisis tentang norma-norma hukum yang telah ditetapkan oleh pejabat yang berwenang untuk itu. ${ }^{5}$ Oleh karena itu, di dalam penelitian tentang kebijakan formulasi sanksi pidana kerja sosial terhadap orang membuang sampah dari kendaraan di Kota Jambi ini, peneliti akan mengkaji norma hukum yang terdapat di dalam Pasal 46 ayat (3) Huruf c Peraturan Daerah Kota Jambi Nomor 5 Tahun 2020 Tentang Pengelolaan Sampah.

Berkaitan dengan penelitian tentang kebijakan formulasi sanksi pidana kerja sosial terhadap orang membuang sampah dari kendaraan di Kota Jambi maka pendekatan yang digunakan dalam penelitian ini adalah pendekatan perundang-undangan (statute approach) dan pendekatan konseptual (conseptualical approach). Pendekatan perundang-undangan merupakan suatu pendekatan yang kajian atau analisisnya terkait dengan semua peraturan perundang-undangan yang berlaku dalam hal ini termasuk juga Peraturan Daerah Kota Jambi Nomor 5 Tahun 2020 Tentang Pengelolaan Sampah.

Dengan melakukan pendekatan perundang-undangan ini maka peneliti perlu memahami berbagai macam peraturan perundang-undangan selain Peraturan Daerah Kota Jambi Nomor 5 Tahun 2020 Tentang Pengelolaan Sampah yang berkaitan dengan penggunaan sanksi pidana kerja sosial terhadap orang membuang sampah dari

\footnotetext{
${ }^{4}$ Sukandarrumidi, Metodologi Penelitian: Petunjuk Praktis untuk Peneliti Pemula, (Yogyakarta : Gajah Mada University Press, 2006), hal 111.

${ }^{5}$ H. Salim HS, Earliest Septiana Nurbani, Penerapan Teori Hukum Pada Penelitian Tesis Dan Disertasi, (Jakarta : PT. Raja Grafindo Persada, 2013), hal 13.
} 
kendaraan di Kota Jambi. Kemudian pendekatan kontekstual (conseptualical approach) yaitu pendekatan yang berpijak pada pandangan atau doktrin yang berkembang pada setiap ilmu termasuk juga dalam hal ini ilmu hukum. Dengan pendekatan konseptual ini, peneliti dapat mengkaji pandangan dan doktrin di dalam ilmu hukum terutama berkaitan dengan penggunaan sanksi pidana kerja sosial terhadap orang membuang sampah dari kendaraan di Kota Jambi.

2. Rancangan Kegiatan

Dalam melakukan suatu penelitian tentu ada rencana kegiatan sehingga penelitian tersebut dapat terselesaikan sesuai dengan jadwal yang telah ditentukan oleh peneliti itu sendiri. Rencana kegiatan di dalam penelitian tentang kebijakan formulasi sanksi pidana kerja sosial terhadap orang membuang sampah dari kendaraan di Kota Jambi dilakukan selama 1 bulan yaitu bulan Mei sampai dengan Juni 2021 guna untuk mendapatkan hasil yang sesuai dalam penelitian ini.

3. Ruang Lingkup Atau Objek

Ruang lingkup dalam penelitian ini bertujuan untuk memberi batasan terkait dengan apa saja yang akan diteliti oleh peneliti. Dengan adanya ruang lingkup ini maka peneliti hanya memfokuskan pada batasan di dalam penelitian tersebut. Adapun ruang lingkup penelitian tentang kebijakan formulasi sanksi pidana kerja sosial terhadap orang membuang sampah dari kendaraan di Kota Jambi ini yaitu mengkaji isi dari norma pada Pasal 46 ayat (3) Huruf c Peraturan Daerah Kota Jambi Nomor 5 Tahun 2020 Tentang Pengelolaan Sampah.

Selanjutnya terkiat dengan objek, objek dalam penelitian yaitu suatu sasaran yang akan diteliti oleh peneliti melalui cara ilmiah. Dalam hal ini Marzuki berpendapat bahwa objek ilmu hukum adalah hukum. ${ }^{6}$ Dengan demikian, objek di dalam penelitian tentang kebijakan formulasi sanksi pidana kerja sosial terhadap orang membuang sampah dari kendaraan di Kota Jambi yaitu asas-asas hukum yang terdapat di dalam Pasal 46 ayat (3) Huruf c Peraturan Daerah Kota Jambi Nomor 5 Tahun 2020 Tentang Pengelolaan Sampah.

4. Bahan Dan Alat Utama

Pada setiap melakukan penelitian tentu ada bahan yang digunakan untuk melakukan kajian penelitian. Bahan yang biasanya digunakan dalam suatu penelitian harus sesuai dengan pokok permasalahan yang sedang diteliti seperti dalam hal ini yaitu meneliti tentang kebijakan formulasi sanksi pidana kerja sosial terhadap orang membuang sampah dari kendaraan di Kota Jambi. Oleh karena itu, dalam penelitian yang bersifat normatif ini bahan hukumnya terdiri dari bahan hukum primer, bahan hukum sekunder dan bahan hukum tersier. ${ }^{7}$

Bahan hukum primer di dalam penelitian hukum normatif berupa peraturan perundang-undangan, yurisprudensi, traktat, perjanjian-perjanjian dan sebagainya. ${ }^{8}$ Jika dikaitkan dengan penelitian tentang kebijakan formulasi sanksi pidana kerja sosial terhadap orang membuang sampah dari kendaraan di Kota Jambi maka bahan hukum primer yang digunakan yaitu peraturan perundang-undangan yang berkaitkan dengan pembuangan sampah dari kendaraan seperti Peraturan Daerah Kota Jambi Nomor 5 Tahun 2020 Tentang Pengelolaan Sampah.

Kemudian bahan hukum sekunder di dalam penelitian hukum normatif berupa naskah akademis, rancangan undang-undang dan hasil penelitian para ahli. ${ }^{9}$ Untuk itu, di dalam penelitian tentang kebijakan formulasi sanksi pidana kerja sosial terhadap orang membuang sampah dari kendaraan di Kota Jambi maka bahan hukum sekundernya menggunakan rancangan undang-undang seperti rancangan Kitab Undang-Undang Hukum Pidana (KUHP) terkait dengan sanksi pidana kerja sosial dan hasil penelitian para ahli berupa buku maupun jurnal yang telah dipublikasi.

Selanjutnya bahan hukum tersier adalah petunjuk atau penjelasan mengenai bahan hukum primer atau bahan hukum sekunder yang berasal dari kamus, ensiklopedia, majalah, surat kabar dan sebagainya. ${ }^{10}$ Dalam hal ini, bahan hukum tersier yang digunakan dalam penelitian tentang kebijakan formulasi sanksi pidana kerja sosial terhadap orang membuang sampah dari kendaraan di Kota Jambi ini berupa surat kabar online yang ada di internet.

Alat utama di dalam suatu penelitian digunakan sebagai pendukung untuk mempermudah peneliti di dalam melakukan suatu penelitian. Namun, di dalam penelitian hukum normatif ini tidak sama alat utama yang digunakan seperti penelitian hukum empiris karena dalam penelitian hukum normatif tidak mengkaji terkait dengan penerapan di lapangan sehingga alat utama dalam penelitian hukum normatif ini berupa dokumen yang berkaitan dengan permasalahan pembuangan sampah dari atas kendaraan.

5. Tempat

Tempat di dalam suatu penelitian menunjukkan lokasi terkait dengan permasalahan sedang diteliti. Di dalam penelitian hukum normatif ini tidak menggunakan tempat untuk melakukan pengkajian terhadap peraturan

\footnotetext{
${ }^{6}$ Ishaq, Metode Penelitian Hukum, (Bandung : Alfabeta, 2017), hal 71.

${ }^{7}$ H. Salim HS, Earliest Septiana Nurbani, Op.Cit, hal 16.

8 Bahder Johan Nasution, Metode Penelitian Ilmu Hukum, (Bandung : CV. Mandar Maju, 2008), hal 86.

${ }^{9}$ H. Salim HS, Earliest Septiana Nurbani, Op.Cit, hal 16.

${ }^{10}$ H. Zainuddin Ali, Metode Penelitian Hukum, (Jakarta : Sinar Grafika, 2009), hal 106.
} 
perundang-undangan, akan tetapi jika dilihat dari judul tentang kebijakan formulasi sanksi pidana kerja sosial terhadap orang membuang sampah dari kendaraan di Kota Jambi maka tempat yang diteliti dalam penelitian normatif ini yaitu Kantor Walikota Jambi. Namun, peneliti tidak sampai ke Kantor Walikota Jambi karena peneliti hanya mengkaji isi norma dalam Pasal 46 ayat (3) Huruf c Peraturan Daerah Kota Jambi Nomor 5 Tahun 2020 Tentang Pengelolaan Sampah saja.

6. Teknik Pengumpulan Data

Teknik pengumpulan data dalam penelitian hukum normatif tentang kebijakan formulasi sanksi pidana kerja sosial terhadap orang membuang sampah dari kendaraan di Kota Jambi yaitu menggunakan studi dokumenter. Digunakan studi dokumen ini karena mengkaji terkait dengan berbagai macam dokumen termasuk juga dokumen yang berkaitan dengan Peraturan Daerah Kota Jambi Nomor 5 Tahun 2020 Tentang Pengelolaan Sampah.

7. Definisi Operasional Variabel Penelitian

Definisi Operasional Variabel Penelitian digunakan untuk menghindari kekeliruan dalam memahami istilah pada penelitian hukum normatif ini sebagaimana tercantum di dalam judul penelitian ini maka penulis memberikan batasan dan definisi secara singkat tentang yang kata-kata yang dianggap penting dalam penelitian ini. Adapun definisi operasional variabel penelitian dalam penelitian tentang kebijakan formulasi sanksi pidana kerja sosial terhadap orang membuang sampah dari kendaraan di Kota Jambi sebagai berikut :

a. Kebijakan Formulasi

Kebijakan merupakan suatu keputusan yang dikeluarkan oleh institusi atau pejabat yang berwenang dan keputusan tersebut berpayung pada peraturan perundang-undangan yang lebih tinggi sebagai dasar terkait dengan keputusan yang dikeluarkan oleh instansi atau pejabat yang berwenang tersebut.

Jika dikaitkan dengan kebijakan formulasi maka kebijakan formulasi merupakan suatu upaya yang dilakukan dalam merumuskan hukum pidana yang akan datang sesuai dengan nilai politik, filosofi dan kultural masyarakat Indonesia dan dituangkan dalam perundang-undangan dimana yang berwenang dalam mengeluarkan upaya tersebut yaitu instansi atau pejabat yang berwenang seperti dalam hal ini Peraturan Daerah Kota Jambi Nomor 5 Tahun 2020 Tentang Pengelolaan Sampah maka yang mengeluarkannya adalah Walikota Jambi.

b. Sanksi Pidana Kerja Sosial

Sanksi pidana merupakan penjatuhan hukuman berupa penderitaan kepada pelaku atas perbuatannya yang melawan hukum, dimana perbuatan tersebut telah diatur dalam peraturan perundang-undangan/hukum tertulis. Selain itu juga, sanksi pidana diberikan kepada laku dengan tujuan untuk memberikan efek jera kepada pelaku yang melakukan perbuatan melawan hukum agar pelaku tersebut tidak mengulangi perbuatan yang sama di kemudian hari.

Kemudian sanksi pidana kerja sosial merupakan salah satu alternatif dalam penjatuhan hukuman kepada pelaku yang melakukan perbuatan melawan hukum baik dalam hal tindak pidana maupun pelanggaran. Sanksi pidana kerja sosial ini merupakan suatu hukuman berupa perampasan kemerdekaan seseorang dalam kurun waktu singkat. Selain itu juga, dalam menerapkan sanksi pidana kerja sosial ini ada syarat-syarat tertentu sehingga pelaku yang dijatuhkan dengan sanksi pidana kerja sosial ini tidak merasa keberatan dalam menjalankan pidana kerja sosial itu sendiri.

c. Sampah

Sampah merupakan hasil yang tidak dapat digunakan lagi bagi manusia sehingga oleh manusia dibuang begitu saja. Selain itu juga, keberadaan sampah tidak bisa lepas dari aktivitas manusia itu sendiri karena sampah merupakan sisa dari berbagai kegiatan manusia sehari-hari. Tidak hanya itu saja, dengan adanya sampah akan menimbulkan banyak polusi udara sehingga sampah tersebut harus menjadi perhatian pemerintah khususnya dalam hal ini pemerintah Kota Jambi dalam melindungi masyarakat Kota Jambi dari bahaya polusi sampah.

d. Kendaraan

Kendaraan merupakan suatu sarana yang digunakan oleh setiap manusia untuk menuju suatu tempat ke tempat lain dalam waktu yang singkat. Selain itu juga, pengertian kendaraan ini juga terdapat dalam Pasal 1 angak 7 Undang-Undang Nomor 22 Tahun 2009 Tentang Lalu Lintas Dan Angkutan Jalan yang menjelaskan bahwa kendaraan adalah suatu sarana angkut di jalan yang terdiri atas Kendaraan Bermotor dan Kendaraan Tidak Bermotor.

e. Kota Jambi

Kota Jambi merupakan sebuah kota yang berada di provinsi Jambi dan Kota Jambi dibelah oleh Sungai Batanghari serta daratannya dihubungkan dengan jembatan Aur Duri. Jika dilihat dari sejarahnya, kota Jambi ini didirikan pada tanggal 28 Mei 1401, kemudian kota Jambi ini resmi menjadi ibukota provinsi Jambi pada 
tanggal 6 Januari 1957 berdasarkan Undang-Undang Darurat Nomor 19 Tahun 1957 Tentang Pembentukan Daerah-Daerah Swatantra Tingkat I Sumatera Barat, Jambi dan Riau. ${ }^{11}$

8. Teknik Analisis

Berdasarkan judul penelitian ini yaitu kebijakan formulasi sanksi pidana kerja sosial terhadap orang membuang sampah dari kendaraan di Kota Jambi maka teknik analisis yang digunakan yaitu analisis kualitatif. Analisis kualitatif pada dasarnya yaitu suatu analisis yang menjelaskan dengan menggunakan kata-kata atas temuan yang dilakukan oleh peneliti. ${ }^{12} \mathrm{Hal}$ ini dikatakan demikian karena analisis kualitatif lebih mengutamakan kualitas daripada data sehingga penjelasan terkait dengan masalah yang sedang dibahas dalam penelitian ini yaitu kebijakan formulasi sanksi pidana kerja sosial terhadap orang membuang sampah dari kendaraan di Kota Jambi menjadi di pokok utama dalam penelitian kualitatif itu sendiri sebab dipaparkan dalam bentuk kalimat yang akan dituangkan dalam pembahasan pada penelitian ini.

\section{HASIL DAN PEMBAHASAN}

\section{Pengaturan Sanksi Denda Terhadap Orang Membuang Sampah Dari Kendaraan Dalam Peraturan Daerah Kota Jambi Nomor 5 Tahun 2020 Tentang Pengelolaan Sampah}

Setiap tingkah laku manusia selalu ada aturan hukum yang mengaturnya sehingga apabila manusia tersebut telah melakukan perbuatan yang menyimpang dari aturan hukum maka akan dikenakan berbagai macam sanksi sesuai dengan sanksi yang tercantum di dalam aturan hukum tersebut seperti contoh dalam hal ini sanksi denda yang tercantum di dalam Peraturan Daerah Kota Jambi Nomor 5 Tahun 2020 Tentang Pengelolaan Sampah. Diberlakukan sanksi denda dalam Peraturan Daerah Kota Jambi Nomor 5 Tahun 2020 Tentang Pengelolaan Sampah guna untuk memberikan pelajaran terhadap orang yang melanggar suatu aturan hukum termasuk jika Peraturan Daerah Kota Jambi Nomor 5 Tahun 2020 Tentang Pengelolaan Sampah sehingga kedepannya tidak ada lagi orang yang melanggar aturan hukum (Peraturan Daerah Kota Jambi Nomor 5 Tahun 2020 Tentang Pengelolaan Sampah) tersebut.

Untuk itu, penjatuhan sanksi denda hanya diberlakukan kepada orang yang tertentu saja yaitu orang yang tidak mentaati Peraturan Daerah Kota Jambi Nomor 5 Tahun 2020 Tentang Pengelolaan Sampah. Pernyataan ini juga sama dengan pendapat moeljatno yang pada intinya menjelaskan bahwa setiap perbuatan yang telah dilarang oleh aturan hukum dan disertai dengan hukuman berupa sanksi bagi pelaku yang telah melakukan pelanggaran dalam aturan hukum tersebut. ${ }^{13}$ Dengan demikian sudah jelas bahwa siapa saja yang melanggar aturan hukum termasuk juga Peraturan Daerah Kota Jambi Nomor 5 Tahun 2020 Tentang Pengelolaan Sampah maka orang tersebut telah dapat dijatuhkan dengan sanksi pidana sesuai di dalam Peraturan Daerah Kota Jambi Nomor 5 Tahun 2020 Tentang Pengelolaan Sampah itu sendiri.

Dengan adanya Peraturan Daerah Kota Jambi Nomor 5 Tahun 2020 Tentang Pengelolaan Sampah maka setiap orang yang membuang sampah tidak sesuai dengan aturan yang telah berlaku maka orang tersebut dapat dikenakan sanksi danda seperti dalam hal orang yang yang membuang sampah dari atas kendaraannya sendiri. Ini telah menunjukkan bahwa dalam hal membuang sampah tidak boleh sewenang-wenang sebab ketika orang yang membuang sampah tidak sesuai dengan aturan hukum atau mau sendiri maka dikhawatirkan akan merugikan orang lain atau pengendara lain dibelakangnya.

Kondisi yang demikian ini sering terjadi di Jalan Raya ketika pengemudi baik sepeda motor maupun mobil sulit untuk menemukan tempat sampah maka secara otomatis baik pengemudi maupun penumpang sepeda motor atau mobil itu membuang sampah secara langsung ditempat yang yang tidak ada tempat sampah sehingga sampah yang dibuang tersebut menjadi berserakan di pinggir jalan. Dengan sampah yang berserakan di pinggir jalan tentunya selain merusak pemandangan di wilayah kota Jambi, dengan adanya sampah tersebut juga menyusahkan petugas kebersihan yang seharusnya mereka mengambil sampah dari bak sampah yang telah ditentukan, akan tetapi harus turun ke pinggir jalan untuk mengambil sampah yang dibuang tidak pada tempatnya.

Tidak hanya itu saja, belum lagi sampah tersebut merupakan sampah basah yang mana akan menimbulkan bau yang tidak sedap sehingga akan mengganggu pernapasan masyarakat disekitarnya dan juga pengendara sepeda motor maupun mobil yang melewati jalan tersebut. Bahkan yang lebih parahnya lagi, apabila sampah tersebut mengenai ban kendaraan sepeda motor orang lain akan mengakibatkan ban sehingga pengendara sepeda motor tersebut dapat jatuh dari motornya.

Mengingat besarnya bahaya yang ditimbulkan dari orang yang membuang sampah dari atas kendaraannya yang mana dari perbuatan tersebut dapat merugikan orang lain maka pemerintah membuat aturan terkait dengan pelarangan orang membuang sampah di atas kendaraan. Pelarangan ini telah diatur dalam Pasal 28 huruf e Peraturan Daerah Kota Jambi Nomor 5 Tahun 2020 Tentang Pengelolaan Sampah yang berisikan bahwa setiap orang, pelaku usaha, dan atau

\footnotetext{
${ }^{11}$ https://kompaspedia.kompas.id/baca/profil/daerah/provinsi-jambi, Diunduh tanggal 5 Juli 2021.

${ }^{12}$ H. Salim HS, Earliest Septiana Nurbani, Op.Cit, hal 19.

${ }^{13}$ Fitrotin Jamilah, Kitab Undang-Undang Hukum Pidana (KUHP), (Jakarta : Dunia Cerdas, 2014), hal 45.
} 
badan usaha dilarang membuang sampah dan/atau kotoran lainnya dari atas kendaraan. Dengan adanya pasal tersebut maka sudah jelas setiap warga negara kota Jambi tidak boleh membuang sampah di atas kendaraannya demi mewujudkan kota Jambi yang bersih dari sampah.

Walaupun telah ada Pasal 28 huruf e Peraturan Daerah Kota Jambi Nomor 5 Tahun 2020 Tentang Pengelolaan Sampah terkait dengan pelarangan warga kota Jambi untuk tidak membuang sampah di atas kendaraannya, akan tetapi pasal ini belum kuat jika diterapkan pada masyarakat kota Jambi karena Pasal 28 huruf e Peraturan Daerah Kota Jambi Nomor 5 Tahun 2020 Tentang Pengelolaan Sampah ini hanya ketentuan umum saja sehingga harus diperkuat lagi dengan ketentuan khusus terkait dengan sanksi terhadap orang yang membuang sampah di atas kendaraan.

Adapun ketentuan lebih khusus terkait dengan sanksi jika orang tersebut melanggar Pasal 28 huruf e Peraturan Daerah Kota Jambi Nomor 5 Tahun 2020 Tentang Pengelolaan Sampah yaitu dikenakan sanksi administrasi berupa sanksi denda. Penerapan sanksi administrasi dengan demikian tidak bisa dipisahkan dari pembahasan/kajian tentang tindak pemerintahan. ${ }^{14}$ Untuk itu, pemerintah Kota Jambi membuat sanksi administrasi dalam Peraturan Daerah Kota Jambi Nomor 5 Tahun 2020 Tentang Pengelolaan Sampah karena merupakan pembahasan pemerintah Kota Jambi terkait dengan sampah di Kota Jambi terutama sampah yang dibuang oleh pengendara sepeda motor maupun mobil dipinggir jalan.

Adapun sanksi denda ini terdapat di dalam Pasal 46 ayat (3) huruf c Peraturan Daerah Kota Jambi Nomor 5 Tahun 2020 Tentang Pengelolaan Sampah yang mana isinya yaitu setiap orang dengan sengaja atau terbukti membuang sampah dari kendaraan, dikenakan denda minimal Rp. 500.000,- (lima ratus ribu rupiah). Dengan demikian, apabila ada masyarakat Kota Jambi yang ketahuan membuang sampah di atas kendaraannya maka oleh pemerintah Kota Jambi terhadap masyarakat kota Jambi tersebut akan dikenakan sanksi administrasi berupa sanksi denda minimal Rp. 500.000,- (lima ratus ribu rupiah).

\section{Implikasi Sanksi Pidana Kerja Sosial Terhadap Orang Membuang Sampah Dari Kendaraan Dalam Peraturan Daerah Kota Jambi Nomor 5 Tahun 2020 Tentang Pengelolaan Sampah}

Apabila dilihat dalam Pasal 46 ayat (3) huruf c Peraturan Daerah Kota Jambi Nomor 5 Tahun 2020 Tentang Pengelolaan Sampah tersebut yang berbunyi yaitu setiap orang dengan sengaja atau terbukti membuang sampah dari kendaraan, dikenakan denda minimal Rp. 500.000,- (lima ratus ribu rupiah). Dalam hal ini sudah terkandung bahwa Siapa saja yang membuang sampah dari atas kendaraannya maka akan dikenakan sanksi berupa denda. Diberikan sanksi administrasi berupa denda terhadap orang yang melakukan perbuatan membuang sampah di atas kendaraannya merupakan teguran kepada pengendara sepeda motor maupun mobil untuk tidak sewenang-wenang di dalam membuang sampah.

Sebenarnya walaupun tidak ada sanksi denda terhadap orang yang membuang sampah di atas kendaraannya tersebut memang sudah kewajiban masyarakat kota Jambi untuk melestarikan lingkungan kota Jambi yang bersih dari berbagai macam sampah. Hal yang demikian juga telah diprogramkan oleh pemerintah kota Jambi terkait dengan melestarikan lingkungan kota Jambi yang bersih sehingga Kota Jambi mendapatkan penghargaan piala Adipura terkait dengan kebersihan. Oleh karena itu, dengan adanya program ini maka pemerintah kota Jambi memberlakukan sanksi administrasi berupa denda terhadap Siapa saja yang melakukan pembuangan sampah di atas kendaraan.

Walaupun telah ada pelarangan terkait dengan pembuangan sampah tidak boleh dilakukan di atas kendaraan, akan tetapi pada fakta dilapangan masih banyak juga masyarakat Kota Jambi membuang sampah dari kendaraannya seperti sampah makanan, bungkus rokok, sampah air minum dan sebagainya. Hal yang demikian apabila dikaitkan dengan isi Pasal 46 ayat (3) huruf c Peraturan Daerah Kota Jambi Nomor 5 Tahun 2020 Tentang Pengelolaan Sampah maka sudah jelas belum efektif di dalam penerapannya sehingga harus dibutuhkan kerjasama antara pemerintah Kota Jambi dengan Masyarakat Kota Jambi dalam menjaga dan melestarikan lingkungan Kota Jambi yang bebas dan bersih dari sampah.

Selain itu juga, adanya sanksi administrasi berupa denda tidak memberikan dampak yang begitu besar terhadap orang yang memiliki uang karena dengan hanya membayar Rp. 500.000,- (lima ratus ribu rupiah) saja orang yang mempunyai uang tersebut yang telah melakukan pembuangan sampah dari kendaraannya, bebas begitu saja tanpa mendapat pelajaran atas perbuatan yang dilakukannya. Seharusnya hukum memberikan suatu pelajaran berupa efek jera terhadap si pelakunya sehingga di kemudian hari pelaku itu tidak mengulangi perbuatan yang sama. Tidak hanya itu saja, dengan adanya sanksi yang tidak dilakukan secara maksimal oleh pemerintah kota Jambi juga tidak memberikan efek jera terhadap pengendara sepeda motor maupun mobil sehingga cukup sulit untuk menerapkan Pasal 46 ayat (3) huruf c Peraturan Daerah Kota Jambi Nomor 5 Tahun 2020 Tentang Pengelolaan Sampah dan tidak mendukung program yang telah diadakan oleh pemerintah kota Jambi.

${ }^{14}$ Sri Nur Hari Susanto, "Karakter Yuridis Sanksi Hukum Administrasi: Suatu Pendekatan Komparasi”, Adminitrative Law \& Governance Journal Vol 2, no.1, (Maret 2019) : 128. 
Namun sebaliknya, dengan adanya sanksi administrasi sebesar Rp. 500.000,- (lima ratus ribu rupiah) ini terhadap orang yang perekonomiannya dikategorikan menengah ke bawah akan merasa berat untuk melakukan pembayaran denda administrasi tersebut. Dengan adanya keberatan dari masyarakat Kota Jambi yang perekonomiannya menengah ke bawah maka pemerintah Kota Jambi harus mengeluarkan solusi agar masyarakat kota Jambi tetap dapat menjalankan hukuman yang diberikan oleh pemerintah kota Jambi terkait dengan perbuatannya yang telah membuang sampah dari kendaraan miliknya. Hal ini dikatakan demikian karena suatu hukum dibuat untuk memberikan perlindungan kepada masyarakatnya termasuk juga dalam hal ini masyarakat kota Jambi sehingga pemerintah kota Jambi sudah seharusnya memikirkan sanksi pidana yang sesuai dengan perbuatan orang yang melakukan pembuangan sampah dari kendaraan selain sanksi administrasi.

Apabila dilihat dari tindak pidana yang dilakukan oleh pelaku yaitu melakukan pembuangan sampah dari kendaraannya maka sanksi pidana yang sesuai dengan perbuatan tersebut berupa sanksi pidana ringan selain pidana denda seperti sanksi pidana kerja sosial. Hal ini juga sesuai dengan isi dalam Draft Rancangan Undang-Undang Tentang Kitab Undang-Undang Hukum Pidana (KUHP) Tahun 2010 yang menjelaskan bahwa apabila pengambilan kekayaan atau pendapatan tidak memungkinkan, maka pidana denda yang tidak dibayar tersebut diganti dengan pidana kerja sosial.

Pidana kerja sosial ini juga terdapat di dalam Rancangan Undang-Undang Tentang Kitab Undang-Undang Hukum Pidana (KUHP) baru Indonesia. Adapun jenis sanksi pidana pokok dalam Draft Rancangan Undang-Undang Tentang Kitab Undang-Undang Hukum Pidana (KUHP) Tahun 2010 sebagai berikut :

1. Pidana penjara

2. Pidana tutupan

3. Pidana pengawasan

4. Pidana denda

5. Pidana kerja sosial.

Dengan adanya sanksi pidana kerja sosial ini bagi masyarakat kota Jambi yang telah melakukan pembuangan sampah dari kendaraannya akan dapat melaksanakan sanksi pidana tersebut karena sesuai dengan perbuatan yang dilakukannya dan juga tidak membebani terhadap pengendara sepeda motor maupun mobil tersebut jika mereka tidak memiliki uang sebesar Rp. 500.000,- (lima ratus ribu rupiah) untuk memenuhi sanksi administrasi berupa denda tersebut yang telah diatur dalam Pasal 46 ayat (3) huruf c Peraturan Daerah Kota Jambi Nomor 5 Tahun 2020 Tentang Pengelolaan Sampah.

\section{Kebijakan Formulasi Sanksi Pidana Kerja Sosial Terhadap Orang Membuang Sampah Dari Kendaraan Dalam Peraturan Daerah Kota Jambi Nomor 5 Tahun 2020 Tentang Pengelolaan Sampah Yang Akan Datang}

Dengan adanya sanksi denda terhadap orang yang membuang sampah dari kendaraan sebagaimana yang telah diatur dalam Pasal 46 ayat (3) huruf c Peraturan Daerah Kota Jambi Nomor 5 Tahun 2020 Tentang Pengelolaan Sampah maka dikhawatirkan tidak akan efektif di dalam penerapannya sebab tidak semua masyarakat kota Jambi memiliki perekonomian diatas rata-rata sehingga akan memberatkan masyarakat kota Jambi khususnya pengendara sepeda motor maupun mobil dalam membayar sanksi denda yang telah ditetapkan oleh pemerintah kota Jambi tersebut. Jika tidak efektif dalam penerapan terkait dengan sanksi denda tersebut maka sangat disayangkan terkait dengan pencantuman sanksi denda terhadap orang yang membuang sampah dari kendaraan tersebut di dalam Peraturan Daerah Kota Jambi Nomor 5 Tahun 2020 Tentang Pengelolaan Sampah sebab suatu Peraturan dibuat harus ditegakkan dan diterapkan terhadap masyarakatnya terutama masyarakat kota Jambi itu sendiri.

Mengingat hal yang demikian maka sudah seharusnya selain diadakan sanksi denda di dalam Pasal 46 ayat (3) huruf c Peraturan Daerah Kota Jambi Nomor 5 Tahun 2020 Tentang Pengelolaan Sampah tersebut juga diatur terkait dengan sanksi pidana kerja sosial sehingga bagi masyarakat kota Jambi terutama pengendara sepeda motor maupun mobil yang melakukan pembuangan sampah di atas kendaraannya dapat menjalankan hukuman tersebut, tanpa harus melakukan pembayaran sanksi administrasi berupa denda sebesar Rp. 500.000,- (lima ratus ribu rupiah). Hal ini dinyatakan demikian karena sesuai dengan tujuan hukum yaitu selain memberikan efek jera juga memberikan pelajaran terhadap si pelaku yang melakukan perbuatan tersebut sehingga kedepannya pelaku itu tidak mengulangi perbuatan yang sama.

Selain itu juga, dimasukkan sanksi pidana kerja sosial di dalam Pasal 46 ayat (3) huruf c Peraturan Daerah Kota Jambi Nomor 5 Tahun 2020 Tentang Pengelolaan Sampah ini sesuai dengan tahap formulasi dalam membuat suatu peraturan terutama Peraturan Daerah Kota Jambi karena dalam tahap formulasi ini merupakan tahapan yang paling strategis di dalam melakukan penanggulangan terhadap masyarakat kota Jambi terkait dengan membuang sampah pada tempatnya. Jika tahapan ini tidak dilakukan dengan sempurna maka akan menimbulkan hambatan di dalam penerapannya seperti contoh jika dilakukan hanya dengan sanksi denda saja maka dikhawatirkan tidak semua 
masyarakat kota Jambi yang telah melakukan pembuangan sampah dari kendaraannya dapat memenuhi atau membayar sanksi denda tersebut.

Pada dasarnya, di dalam kebijakan formulasi hukum pidana mengupayakan terkait dengan pencapaian tujuan melalui kebijakan kriminal dengan menggunakan sarana hukum pidana (penal). Oleh karena itu, sudah seharusnya sanksi pidana kerja sosial ini dicantumkan di dalam Peraturan Daerah Kota Jambi Nomor 5 Tahun 2020 Tentang Pengelolaan Sampah guna untuk mencapai tujuan hukum yaitu menjaga kelestarian dan kebersihan Kota Jambi dan memberikan pelajaran atau efek jera terhadap pengendara sepeda motor maupun mobil yang melakukan pembuangan sampah dari kendaraannya. Jika kondisi seperti ini telah dilakukan maka secara tidak langsung pemerintah Kota Jambi telah melakukan penanggulangan terkait dengan pembuangan sampah di sembarang tempat di Kota Jambi.

Diaturnya sanksi pidana kerja sosial di dalam Peraturan Daerah Kota Jambi Nomor 5 Tahun 2020 Tentang Pengelolaan Sampah ini merupakan pembentukan suatu Peraturan Daerah Kota Jambi baru yang mana perbuatan tersebut sebelumnya belum dikategorikan sebagai tindak pidana atau pelanggaran, dengan diaturnya sanksi pidana kerja sosial ini maka perbuatan berupa pembuangan sampah dari kendaraan tersebut merupakan suatu tindak pidana atau pelanggaran. Hal ini juga sama dengan pendapat Sudarto yang menjelaskan bahwa suatu perbuatan yang dapat dijadikan sebagai tindak pidana (kriminalisasi) sebagaimana yang dirumuskan dalam undang-undang pidana dan dapat diancam dengan pidana. ${ }^{15}$ Untuk itu, harus ada aturan hukum terlebih dahulu terkait dengan perbuatan yaitu membuang sampah dari kendaraan dan harus ada ada sanksi pidana sehingga terhadap si pelakunya dapat dikenakan sanksi pidana sesuai dengan aturan hukum tersebut.

Selain itu juga, sanksi pidana kerja sosial yang dimaksud dalam hal ini yaitu memberikan suatu sanksi berupa pekerjaan sosial seperti membersihkan sampah di pinggir jalan dan di tempat umum bersama dengan pekerja kebersihan dari Dinas Lingkungan Hidup Kota Jambi. Hal ini dikatakan demikian karena sanksi pidana kerja sosial sebenarnya telah diadopsi di dalam Rancangan Kitab Undang-Undang Hukum Pidana baru Indonesia (RKUHP). Sebenarnya diadakan sanksi pidana sosial ini guna untuk mengefektifkan hukum pidana agar dapat diterapkan di dalam kehidupan masyarakat oleh penegak hukum dan adanya sanksi pidana kerja sosial ini merupakan sanksi pidana yang lebih manusiawi sehingga terhadap siapa saja yang melakukan pembuangan sampah di atas kendaraannya tidak merasa malu dibandingkan dengan sanksi pidana, dimana si pelanggar harus dijatuhkan hukuman berupa kurungan penjara.

Tidak hanya itu saja, dengan adanya sanksi pidana kerja sosial ini juga tidak membebani pelanggar jika tidak mempunyai uang karena sanksi pidana denda itu harus dibayar oleh si pelanggar yang membuang sampah di atas kendaraan. Untuk itu, sanksi pidana kerja sosial ini sebenarnya lebih membantu kepada si pelanggar agar mempermudah mereka untuk menjalankan sanksi yang harus mereka kerjakan karena sesuai dengan perbuatan yang mereka lakukan yaitu membuang sampah di atas kendaraannya. Walaupun bersifat tidak menimbulkan dampak yang besar namun sanksi pidana sosial ini jika diterapkan kepada masyarakat Kota Jambi maka akan menumbuhkan rasa peduli terhadap lingkungan sekitar terkait dengan kebersihan dan menanamkan pada diri setiap masyarakat Kota Jambi untuk selalu melestarikan lingkungan yang bersih dan bebas dari sampah.

Dengan adanya sanksi pidana kerja sosial ini akan memberikan alternatif kepada pemerintah kota Jambi dan juga kepada si pelanggar guna untuk menjaga kenyamanan dan kebersihan Kota Jambi. Selain itu juga, Dengan adanya tahapan formulasi ini menunjukkan bahwa adanya tugas dan kewajiban pemerintah kota Jambi untuk memantau dan mengawasi setiap pengendara sepeda motor maupun mobil yang nantinya jika terjadi pelanggaran terkait dengan pembuangan sampah dari kendaraan tersebut maka akan segera diterapkan baik sanksi denda maupun sanksi pidana kerja sosial tersebut. Diterapkan sanksi pidana kerja sosial kepada pengendara sepeda motor maupun mobil terkait dengan pembuangan sampah dari kendaraannya guna untuk memberikan pelajaran kepada mereka agar tidak membuang sampah sembarangan dan menghargai pekerjaan Dinas Kebersihan yang bertugas membersihkan sampah di pinggir jalan raya.

Tidak hanya itu saja, tahapan formulasi ini sebenarnya sangat erat dengan politik hukum pidana karena di dalam politik hukum pidana menjelaskan bahwa usaha untuk mewujudkan suatu perundang-undangan pidana harus sesuai dengan keadaan dan situasi pada saat itu dan untuk yang akan datang. Untuk itu, dengan adanya pengaturan terkait dengan sanksi pidana kerja sosial ini jika dicantumkan di dalam Peraturan Daerah Kota Jambi yang akan datang maka akan memberikan dampak baik dalam mencegah dan menanggulangi agar tidak terjadi lagi pembuangan sampah dari kendaraan yang dilakukan oleh pengendara maupun penumpang sepeda motor atau mobil. Jika diterapkan sanksi pidana kerja sosial ini oleh pemerintah kota Jambi maupun aparat penegak hukum maka selain memberikan penderitaan kepada si pengendara maupun penumpang kendaraan sepeda motor atau mobil tersebut, sanksi pidana kerja sosial ini juga merupakan sanksi yang masih bersifat manusiawi karena tidak membebankan begitu berat kepada pelakunya dalam menjalankan sanksi tersebut.

${ }^{15}$ Sudarto, Hukum Dan Hukum Pidana, (Bandung: Alumni, 1977), hal 159. 


\section{SIMPULAN}

1. Pengaturan sanksi denda terhadap orang yang membuang sampah dari kendaraan dalam Peraturan Daerah Kota Jambi Nomor 5 Tahun 2020 Tentang Pengelolaan Sampah adalah diatur di dalam Pasal 46 ayat (3) huruf c Peraturan Daerah Kota Jambi Nomor 5 Tahun 2020 Tentang Pengelolaan Sampah Terkait dengan sanksi denda minimal Rp. 500.000,- (lima ratus ribu rupiah) kepada setiap orang dengan sengaja atau terbukti membuang sampah dari kendaraan. Pengaturan sanksi denda ini merupakan salah satu sanksi administrasi yang dikeluarkan oleh pemerintah kota Jambi di dalam menanggulangi terjadinya pembuangan sampah dari kendaraan yang dilakukan oleh pengendara maupun penumpang sepeda motor atau mobil di jalan raya.

2. Implikasi sanksi pidana kerja sosial terhadap orang membuang sampah dari kendaraan dalam Peraturan Daerah Kota Jambi Nomor 5 Tahun 2020 Tentang Pengelolaan Sampah adalah selain memberi efek jera juga memberi pelajaran terhadap orang yang membuang sampah dari kendaraan sehingga tidak mengulangi perbuatannya lagi dan memberi kemudahan kepada masyarakat kota Jambi yang telah melanggar larangan untuk tidak membuang sampah dari kendaraan untuk menjalankan hukuman sesuai dengan perbuatan yang dilakukannya.

3. Kebijakan formulasi sanksi pidana kerja sosial terhadap orang membuang sampah dari kendaraan dalam Peraturan Daerah Kota Jambi Nomor 5 Tahun 2020 Tentang Pengelolaan Sampah yang akan datang adalah Sebaiknya sanksi pidana kerja sosial harus diberlakukan dalam Peraturan Daerah Kota Jambi Nomor 5 Tahun 2020 Tentang Pengelolaan Sampah Karena dengan adanya sanksi pidana kerja sosial tersebut secara tidak langsung, selain tidak memberatkan bagi yang melakukan perbuatan tersebut juga merupakan suatu upaya penanggulangan agar kedepannya tidak ada lagi masyarakat kota Jambi terutama pengendara sepeda motor maupun mobil yang membuang sampah dari kendaraannya.

\section{DAFTAR PUSTAKA \\ Buku}

Ali, H. Zainuddin, Metode Penelitian Hukum, Jakarta : Sinar Grafika, 2009

HS, H. Salim, Earliest Septiana Nurbani, Penerapan Teori Hukum Pada Penelitian Tesis Dan Disertasi, Jakarta : PT. Raja Grafindo Persada, 2013

Ishaq, Metode Penelitian Hukum, Bandung : Alfabeta, 2017

Jamilah, Fitrotin, Kitab Undang-Undang Hukum Pidana (KUHP), Jakarta : Dunia Cerdas, 2014

Mertokusumo, Sudikno, Mengenal Hukum : Sebuah Pengantar, Yogyakarta : Liberty, 2008

Nasution, Bahder Johan, Metode Penelitian Ilmu Hukum, Bandung : CV. Mandar Maju, 2008

Rahardjo, Satjipto, Ilmu Hukum, Bandung : PT. Citra Aditya Bakti, 2000

Sudarto, Hukum Dan Hukum Pidana, Bandung: Alumni, 1977

Sukandarrumidi, Metodologi Penelitian: Petunjuk Praktis untuk Peneliti Pemula, Yogyakarta : Gajah Mada University Press, 2006

\section{Peraturan Perundang-Undangan}

Republik Indonesia, Undang-Undang Darurat Nomor 19 Tahun 1957 Tentang Pembentukan Daerah-Daerah Swatantra Tingkat I Sumatera Barat, Jambi dan Riau

Republik Indonesia, Undang-Undang Nomor 22 Tahun 2009 Tentang Lalu Lintas Dan Angkutan Jalan

Republik Indonesia, Draft Rancangan Undang-Undang Tentang Kitab Undang-Undang Hukum Pidana (KUHP) Tahun 2010

Republik Indonesia, Peraturan Daerah Kota Jambi Nomor 5 Tahun 2020 Tentang Pengelolaan Sampah

\section{Jurnal}

Susanto, Sri Nur Hari, "Karakter Yuridis Sanksi Hukum Administrasi: Suatu Pendekatan Komparasi”, Adminitrative Law \& Governance Journal Vol 2, no.1, (Maret 2019) : 128

\section{Website}

https://kompaspedia.kompas.id/baca/profil/daerah/provinsi-jambi 